\title{
Assessment of Pesticide use Practice Impact on Honeybee Colony in Selected Districts of East Shoa and West Arsi Zones of Oromia, Ethiopia
}

\author{
Desta Abi ${ }^{1^{*}}$, Taye Beyene ${ }^{2}$, Mekonnen W/Tsadik \\ Adami Tulu Agricultural Research Center (ATARC), Oromia Agricultural Research Institute (IQQO)
}

*Corresponding Author: Desta Abi Gemedi, Adami Tulu Agricultural Research Center (ATARC), Oromia Agricultural Research Institute (IQQO)

\begin{abstract}
During 2009/2010, study was carried out to appraise agrochemicals use practice and its potential risk on honeybees and beekeeping activities in selected districts of East Shoa and West Arsi zones of Oromia. A total of 240 farmer respondents from eight rural peasant associations in four districts were interviewed using pretested partially structured questionnaires. Focus group discussion was held in all eight previously surveyed rural peasant associations for further substantiation of the collected data. About $83.3 \%$ of the study participants used different types of agrochemicals (insecticides, herbicides and fungicides) at different levels. Accordingly $50.8 \%, 22.2 \%, 13.3 \%, 7.9 \%, 3.8 \%$ and $2.1 \%$ of the respondents did use agrochemicals for fungal, insect, weed, quality product, others and other diseases in decreasing order of importance respectively. Majority of Farmers in the study area have practiced spray form of agrochemicals application as compared to other forms. Even though, there is variations, farmers apply agrochemicals mainly at flowering stage of nearly all cultivated crops. Most of the farmers apply agrochemicals during winter season following irrigation farming in the study area. The respondent farmers confirmed that agrochemicals had affected beekeeping activities in several ways. From the respondents view and assessment in the present study, it is evident to report that agrochemical are recklessly used and do have high risk to beekeeping activities and honeybees population in the study area.
\end{abstract}

Therefore, all stake takers should cooperate to mitigate agrochemicals use practice related loss of biodiversity in general and decline of honeybee population in the ecosystem in particular. Frequent training has to be provided for both beekeepers and crop growers on the sustainable use of agrochemicals and approaches that will lessen potential harm that might be posed to honeybees due to misuse of agrochemicals. Further study is needed to examine actual impact of agrochemicals on beekeeping and honeybees using a rigorous research approach under laboratory and field conditions.

Keywords: pesticides, survey, honeybee colony, risk.

\section{INTRODUCTION}

For several decades now outbreak of pests and diseases of agricultural crops has led to excessive use of agrochemicals in developing countries. Agrochemicals use has been used protect pests and diseases of agricultural crops to boost production and ensure food security. In most countries the use of pesticides in agriculture is an accepted practice as it ensures a reliable yield of good quality produce (Sánchez-Bayo, 2011).

However, the unchecked and misuse of agrochemicals has reportedly been brought about the loss of biodiversity (Douglas, 2019). This phenomena has been acknowledged to be extensive and even serious in developing countries as farming activities are always characterized with low skill and improper use of agricultural technologies (Muhammad.A., 2017). Agrochemicals choice in the developing world is often older, broad-spectrum compounds belonging to the organophosphate, organ chlorine and carbamate classes chemical families noted for their acute toxicity (S.K. Biswas, 2014). It could be from potential pesticide exposures from living near farm, in an agricultural spray area, near a pesticide factory, or other environmental exposures and consuming pesticide contaminated food (Bura, 2013). As a matter of fact, misuse of agrochemicals has been known to harm non-target organisms ranging from beneficial soil microorganisms to insects, plants, fishes, and birds in the ecosystem (S.K. Biswas, 2014). 
Although agricultural chemicals use in Ethiopia was historically low, recently increased trends of irrigation based agricultural production has resulted in higher consumption of chemical pesticides (Asogwa, 2009).

Recently, Ethiopia has been considered as having the largest accumulations of obsolete pesticides in the whole of Africa. It was estimated that there were 402 stores at 250 sites containing 1, 500 tones of obsolete pesticides (MOARD, 2007,). This estimate does not include the massive but unquantifiable amounts of pesticides soaked in soils. Nor does it include contaminated building materials, pallets, shipping containers and other miscellaneous items. ANNEX (6)

Therefore it is important to assess the risk posed by the multitude of different pesticides that are used within the agricultural communities at this point in time. Name (03

Good pesticide management practices could help to minimize the risks of pesticide poisoning and pollution of the environment. Some of the good management practices to consider when working with pesticide are: follow pesticide label directions, use protective devices, avoid spills, disposal of pesticide wastes and containers properly, elimination of unnecessary application and use of proper pesticide storage [7].

How many of the Ethiopian farmers are aware of the good pesticide management practices? Do they have awareness about health effects of various pesticides being utilized? To answer such questions one has to research out or evaluate pesticide use and practice in the country. It is unfortunate that there are very limited studies that address this subject in the country. For example in rift valley state farms such as Middle Awash and Upper Awash Agro Industry Enterprise are among the place where there was an intensive past history of pesticide application $[2,8)$.

In 2009 a survey was made, on 226 farmers in other parts of the country, (Sidama zone,) on the practice and risk associated with the utilization of pesticide in the zone. The result of the Shemsu Ligani.; Haya: Saudi J. Life Sci.; Vol-1, Iss-3(Jul-Sep, 2016):103-108 Available Online: http://scholarsmepub.com/haya/ 104 study showed that $174(77 \%)$ of the farmers use DDT for agriculture pest control [9].

Therefore, the actual situation in Ethiopian farmers is alarming and calls for an intensive work on assessing pesticide use and practice, educating the farmers on good (Bura, 2013) pesticide managements; sensitize the local community about consequences in misuse of pesticides. In this study one of the largest Districts of Borena Zone in the Oromya region of Ethiopia was considered to survey the pesticide use and practice of farmers. To our knowledge no study has been made to investigate the status of pesticide use and practice in the area. Therefore, this study is the first of its kind aimed to assess pesticide use and practice in the District.

\section{METHODOLOGY}

\subsection{Study Sites}

The study was conducted in Dugda, Lume (East shoa), Negele Arsi and Dodela (west Arsi) Zones of oromia, Ethiopia.

\subsection{Study Population and Sample Size}

The Source of population included beekeeping farmers in districts located in East Shoa and West Arsi zones of Oromia, Ethiopia. The number of farmers to be included in the study (participants) was determined using single population proportion formula. Because similar studies were not found in the study area, taking the assumption that $50 \%$ of the farmers had low level of knowledge regarding to good pesticides practice. $n=(Z \alpha / 2) 2 p(1-p)$ and the final sample size was 422. D2

\subsection{Data Collection Tools}

An structured questionnaire was used as a data collection tool. The questionnaire was developed by referring different literatures and modified according to the objectives of this study. The questionnaire has four parts which enabled to collect information on general background to the household and farmers, pesticide practice, pesticide knowledge and perception and pesticide use and effects on beekeeping. The questionnaire was first developed in English and it was translated in to local language (Oromifa) for data collection. Prior to data collection, the questionnaire was pre-tested on 
selected farmers in the study area which were not including in the main data collection. It was, therefore, check for its clarity and some corrections were made.

\subsection{Sampling Procedures}

Just before the sampling process, personnel's and extension workers in agricultural and rural development offices were interviewed. This is because the data source was considered to be important since there was no prior knowledge about particular Kebeles in which farmers are keeping bees and using pesticides. Two rural kebeles were purposively selected per each district totaling to 8 rural Kebeles. These study rural kebeles were selected based on the information received from the agricultural experts in agricultural and rural office for the study. Kebele based cross-sectional comparative study was conducted using self administered questionnaires. Households also selected randomly from chosen Kebeles and the intended data was collected according to aim of the study.

\subsection{Data Analysis and Treatment}

Frequency and percentage were used to describe the profile of the respondents in terms of sociodemographic, educational and beekeeping practices and pesticide utilization related factors. Results were presented using charts and tables.

\section{RESULTS AND DISCUSSION}

\subsection{Socio-Demographic Characteristics}

The description of some important socio-demographic characteristics of the respondents of the current study is given in table.1.The mean age of study participants was 43.5 with minimum of 15 years and maximum of 70 years. $(93 \%)$ were male and $(7 \%)$ were female. $(33.5 \%)$ were illiterate, $(7.5 \%)$ were with basic education, $(18.3 \%)$ were with grade $1-4,(23.3 \%)$ were with grade 5-8 and (15\%) were with high school level, $(0.41 \%)$ were with certificate and $(1.7 \%)$ were with diploma/degree level. most of the respondents $(83.3 \%)$ were married,(6.7\%) were both unmarried and divorced while few (3.3\%) were widowed.

Table1. Proportion of household characteristics of the sampled beekeepers of the study area

\begin{tabular}{|c|c|c|c|}
\hline Socio economic indicators & Categories & (n) & $(\%)$ \\
\hline \multirow[b]{2}{*}{ sex } & Male & 223 & 93 \\
\hline & Female & 17 & 7.0 \\
\hline \multirow{4}{*}{ Marital status } & Married & 200 & 83.3 \\
\hline & single & 16 & 6.7 \\
\hline & widowed & 8 & 3.3 \\
\hline & Divorced & 16 & 6.7 \\
\hline \multirow{8}{*}{ Educational status } & & & \\
\hline & Illiterate & 81 & 33.75 \\
\hline & Basic education & 18 & 7.50 \\
\hline & Grade 1-4 & 44 & 18.3 \\
\hline & Grade 5-8 & 56 & 23.3 \\
\hline & Grade $9-12$ & 36 & 15 \\
\hline & Certificate & 1 & 0.41 \\
\hline & Diploma/Degree & 4 & 1.7 \\
\hline \multirow{4}{*}{ Age } & $\leq 15$ & 3 & 1.25 \\
\hline & $15-24$ & 33 & 13.75 \\
\hline & $24-64$ & 112 & 46.7 \\
\hline & $\geq 64$ & 91 & 37.9 \\
\hline \multirow{3}{*}{ Religion } & Muslim & 121 & 50.4 \\
\hline & Orthodox & 82 & 34.2 \\
\hline & Protestant & 37 & 15.4 \\
\hline
\end{tabular}

\subsection{Agricultural Land Resource and Farming Condition}

The respondents allocate their agricultural land for different purposes. Accordingly, farmers allocated $1.9 \pm 1.5$ for cultivated land under rain fed condition with a range of $12 ; 0.06 \pm 0.15$ for cultivated land under irrigation with a range of $0.5 ; 0.24 \pm 0.34$ for grazing land with a range of $0.5 ; 0.07 \pm 0.21$ for 
forestation with a range of $1 ; 0.56 \pm 0.20$ was eroded land with a range of $1 ; 0.40 \pm 0.14$ for homestead with a range of $4 ; 0.053 \pm 0.04$ as mountainous with a range of 0.25 ; and $0.10 \pm 0.06$ for lake with a range of 0.5 .

Table2. Mean+SD hectare of agricultural land as classified by farming category of respondents

\begin{tabular}{|c|c|c|c|c|c|}
\hline \multirow{2}{*}{ Agricultural land use class } & \multicolumn{5}{|c|}{ Description of the land use system } \\
\cline { 2 - 5 } & $\mathrm{N}$ & Mean $+\mathrm{SD}$ & Min. & Max. & Range \\
\hline rain fed & 240 & $1.9 \pm 1.5$ & 0.00 & 12.00 & 12.00 \\
\hline irrigation & 228 & $0.06 \pm 0.15$ & 0.00 & 0.50 & 0.50 \\
\hline Grazing & 240 & $0.24 \pm 0.34$ & 0.00 & 2.00 & 2.00 \\
\hline Forest & 236 & $0.07 \pm 0.21$ & 0.00 & 1.00 & 1.00 \\
\hline Eroded & 240 & $0.56 \pm 0.20$ & 0.00 & 1.00 & 1.00 \\
\hline Homestead & 240 & $0.40 \pm 0.14$ & 0.00 & 4.00 & 4.00 \\
\hline Mountainous & 234 & $0.053 \underline{ \pm 0.04}$ & 0.00 & 0.25 & 0.25 \\
\hline Lake & 240 & $0.10 \pm 0.06$ & 0.00 & 0.50 & 0.50 \\
\hline others & 222 & $0.00 \pm 0.00$ & 0.00 & 0.00 & 0.00 \\
\hline
\end{tabular}

\subsection{Beekeeping Practices}

In this study respondents were engaged in beekeeping activities with apparently differing proportions (Table 3). At the time of this study, (90.8\%) of the respondents had honeybee colonies; whereas (9.2\%) of them do not have honeybee colonies. Most of the respondents $(62.1 \%)$ had awareness that honeybee colonies can improve productivity of cultivated crops through pollination and $(37.9 \%)$ of the respondents do not believe that honeybees can improve productivity of cultivated crops. However, most of the respondents have a low $(50 \%)$ to moderate $(38.75 \%)$ believe that honeybees are important for improving productivity of cultivated crops. But very few $(11.25 \%)$ of the respondents said that honeybees are highly important for improving productivity of cultivated crops

Table3. Proportion of beekeeping practices of respondents in the study area

\begin{tabular}{|c|c|c|c|}
\hline Variable & Variable value & (n) & $(\%)$ \\
\hline \multirow{2}{*}{ Do you have honeybee colony? } & Yes & 218 & 90.80 \\
\cline { 2 - 4 } & No & 22 & 9.20 \\
\hline \multirow{2}{*}{$\begin{array}{c}\text { Do you know honeybees are important for } \\
\text { improving crops productivity }\end{array}$} & Yes & 149 & 62.10 \\
\cline { 2 - 4 } If yes, what is the level of importance for & No & 91 & 37.90 \\
\cline { 2 - 4 } improving crops productivity & High & 27 & 11.25 \\
\cline { 2 - 4 } & Moderate & 93 & 38.75 \\
\hline
\end{tabular}

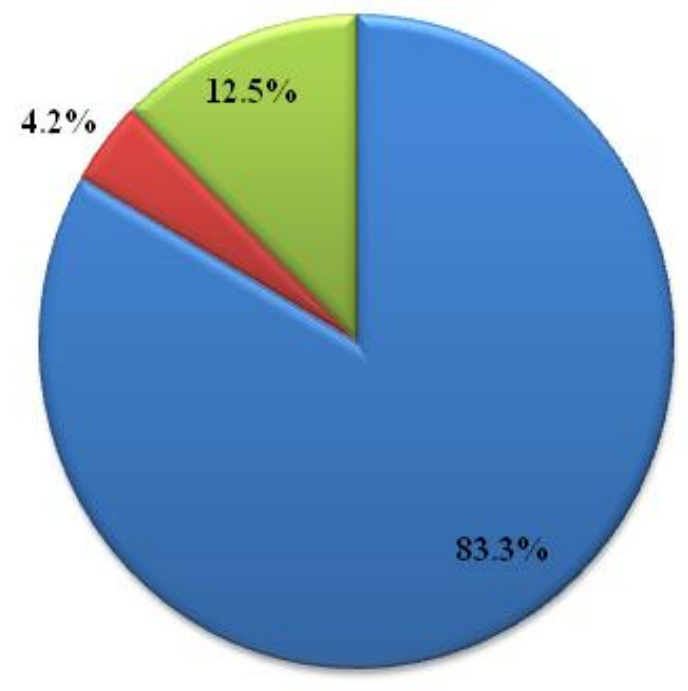

Figure1. Proportion of respondents agrochemicals use in the study areas 
Assessment of Pesticide use Practice Impact on Honeybee Colony in Selected Districts of East Shoa and West Arsi Zones of Oromia, Ethiopia

\subsection{Agrochemicals use Practices}

Majority of farmers used agrochemicals to improve the yield of their agricultural products by preventing foreign plants or insect pests and diseases especially during the time it occurs on a large scale (Fi.1). In this study, 83.3\% of the respondent (beekeepers) were using agrochemicals in their localities. This result has been found to be comparable with finding of Desalegn Begna, (2015) who has reported that $84.3 \%$ of the respondents used pesticides and among which about $61 \%$ of the pesticides used by the farmers were identified as herbicides, $21 \%$ insecticides and $18 \%$ both types at western Amhara. Our study has also verified that $78.9 \%, 57.6 \%$ and $40.4 \%$ of the sampled respondents were using pesticides to protect the crops from pests, herbicides to control weeds and chemicals (DDT) as anti malaria respectively (Figure 13). Yet, $4.2 \%$ and $12.5 \%$ of the respondents did not use agrochemicals and even did not have the idea of agrochemicals use respectively.

It was identified that the farmers in the study area used agrochemicals of different types (Table 4).The respondents specified that the types of agrochemicals used in the study area includes pesticides, herbicides and fungicides. Fifty (50) different agrochemicals were documented (Table 5) out of which thirteen commonly used agrochemicals have been identified under farmers condition (Table 4).

Table4. List of the agrochemicals used in the study area

\begin{tabular}{|c|c|c|c|c|c|c|c|}
\hline No. & $\begin{array}{c}\text { Pesticide } \\
\text { trade name }\end{array}$ & $\begin{array}{c}\text { Pesticide use } \\
\text { type }\end{array}$ & $\begin{array}{c}\text { Target } \\
\text { pest }\end{array}$ & $\begin{array}{c}\text { Target pest } \\
\text { category }\end{array}$ & $\begin{array}{c}\text { Application } \\
\text { rate(L/ha) }\end{array}$ & $\begin{array}{c}\text { Spray } \\
\text { volume (L) }\end{array}$ & $\begin{array}{c}\text { Frequency of } \\
\text { application }\end{array}$ \\
\hline 1 & 2-4D & Herbicide & & weed & & & \\
\hline 2 & Atlantis & Herbicide & & weed & & & \\
\hline 3 & Palace & Herbicide & & weed & & & \\
\hline 4 & Tilt & Fungicide & & Fungus & & & \\
\hline 5 & Topic & Fungicide & & Fungus & & & \\
\hline 6 & Natura & Fungicide & & Fungus & & & \\
\hline 7 & Carate & Herbicide & & weed & & & \\
\hline 8 & U-46 & Fungicide & & Fungus & & & \\
\hline 9 & Agro & Fungicide & & Fungus & & & \\
\hline 10 & Ridomel & Fungicide & & Fungus & & & \\
\hline 11 & Rashido & Fungicide & & Fungus & & & \\
\hline 12 & Rexcido & Fungicide & & Fungus & & & \\
\hline 13 & Endosulfun & & & & & & \\
\hline
\end{tabular}

Table5. List of agrochemicals existing in the local market/pesticide stores

\begin{tabular}{|c|c|c|c|c|c|c|c|}
\hline No. & Common name & $\begin{array}{l}\text { Pesticide } \\
\text { use class }\end{array}$ & $\begin{array}{c}\text { Target } \\
\text { pest }\end{array}$ & $\begin{array}{c}\text { Target } \\
\text { pest } \\
\text { category }\end{array}$ & $\begin{array}{l}\text { Application } \\
\text { rate(L/ha) }\end{array}$ & $\begin{array}{c}\text { Spray } \\
\text { volume(L) }\end{array}$ & $\begin{array}{l}\text { Frequency } \\
\text { of } \\
\text { application }\end{array}$ \\
\hline 1 & $2-4 D$ & Herbicide & & weed & & & \\
\hline 2 & Atlantis & Herbicide & & weed & & & \\
\hline 3 & Palace & Herbicide & & weed & & & \\
\hline 4 & Tilt & Fungicide & & Fungus & & & \\
\hline 5 & Topic & Fungicide & & Fungus & & & \\
\hline 6 & Natura & Fungicide & & Fungus & & & \\
\hline 7 & Carate & Herbicide & & weed & & & \\
\hline 8 & U-46 & Fungicide & & Fungus & & & \\
\hline 9 & Agro & Fungicide & & Fungus & & & \\
\hline 10 & Ridomel & Fungicide & & Fungus & & & \\
\hline 11 & Rashido & Fungicide & & Fungus & & & \\
\hline 12 & Rexcido & Fungicide & & Fungus & & & \\
\hline 15 & Logger & Fungicide & & Fungus & & & \\
\hline 16 & Malathion & Herbicide & & Weed & & & \\
\hline 17 & Mancozeb & Herbicide & & Fungus & & & \\
\hline 18 & Tutan & Fungicide & & Fungus & & & \\
\hline 19 & Galigal & Herbicide & & Weed & & & \\
\hline 20 & Supergalant & Herbicide & & Weed & & & \\
\hline 21 & Bassagram & Herbicide & & Weed & & & \\
\hline
\end{tabular}


Assessment of Pesticide use Practice Impact on Honeybee Colony in Selected Districts of East Shoa and West Arsi Zones of Oromia, Ethiopia

\begin{tabular}{|c|c|c|c|c|c|c|c|}
\hline 22 & fusiled & Herbicide & & Weed & & & \\
\hline 23 & stomp & Herbicide & & Weed & & & \\
\hline 24 & Dimethiote & Insecticide & & Weed & & & \\
\hline 25 & Hanclopa & Wormicide & bollworm & Worm & & & \\
\hline 25 & Helarate & Wormicide & cat worm & Worm & & & \\
\hline 26 & Alpha-cyproid & insecticide & Aphids & Insect & & & \\
\hline 27 & perfecto & Insecticide & trips & Insect & & & \\
\hline 28 & Bestfield & Insecticide & trips & Insect & & & \\
\hline 28 & Malamare/malathion & Wormicide & $\begin{array}{c}\text { stalk } \\
\text { worm }\end{array}$ & Worm & & & \\
\hline 29 & Ethiolathion & Insecticide & trips & Insect & & & \\
\hline 30 & Globe & Insecticide & Trips & Insect & & & \\
\hline 31 & Locslay & Insecticide & Trips & Insect & & & \\
\hline 32 & proven & Wormicide & $\begin{array}{l}\text { Stalk } \\
\text { borer }\end{array}$ & Worm & & & \\
\hline 33 & Decis & Insecticide & & Insect & & & \\
\hline 34 & prayor & Fungicide & & Fungus & & & \\
\hline 35 & Confidence & Fungicide & & Fungus & & & \\
\hline 36 & profid & Fungicide & & Fungus & & & \\
\hline 37 & Matco & Fungicide & & Fungus & & & \\
\hline 38 & Cropaxyl & fungicide & & Fungus & & & \\
\hline 39 & Cropzeb & Fungicide & & Fungus & & & \\
\hline 40 & Unizeb & Fungicide & & Fungus & & & \\
\hline 41 & Mancolaxyl & Fungicide & & Fungus & & & \\
\hline 42 & Amstar & fungicide & & Fungus & & & \\
\hline 43 & Rebus & Fungicide & & Fungus & & & \\
\hline 44 & Nativo & Fungicide & & Fungus & & & \\
\hline 45 & roundup & Fungicide & & Fungus & & & \\
\hline 46 & Greenstar & Herbicide & & weed & & & \\
\hline 47 & Dipricon & Fungicide & & Fungus & & & \\
\hline 48 & Jaba & Fungicide & & Fungus & & & \\
\hline 49 & Crust & Wormicide & & worm & & & \\
\hline 50 & Diaznone & Wormicide & & Worm & & & \\
\hline
\end{tabular}

Respondents were questioned to explain purpose of using agrochemicals in their locality. Respondents mentioned the reasons of use of agrochemicals were for protection of crop pests, fungicides, other diseases and also for quality products (figure 2). Accordingly 50.8\%, 22.2\%, 13.3\%, 7.9\%, 3.8\% and $2.1 \%$ of the respondents did use agrochemicals for fungal, insect, weed, quality product, others and other diseases in decreasing order of importance respectively.

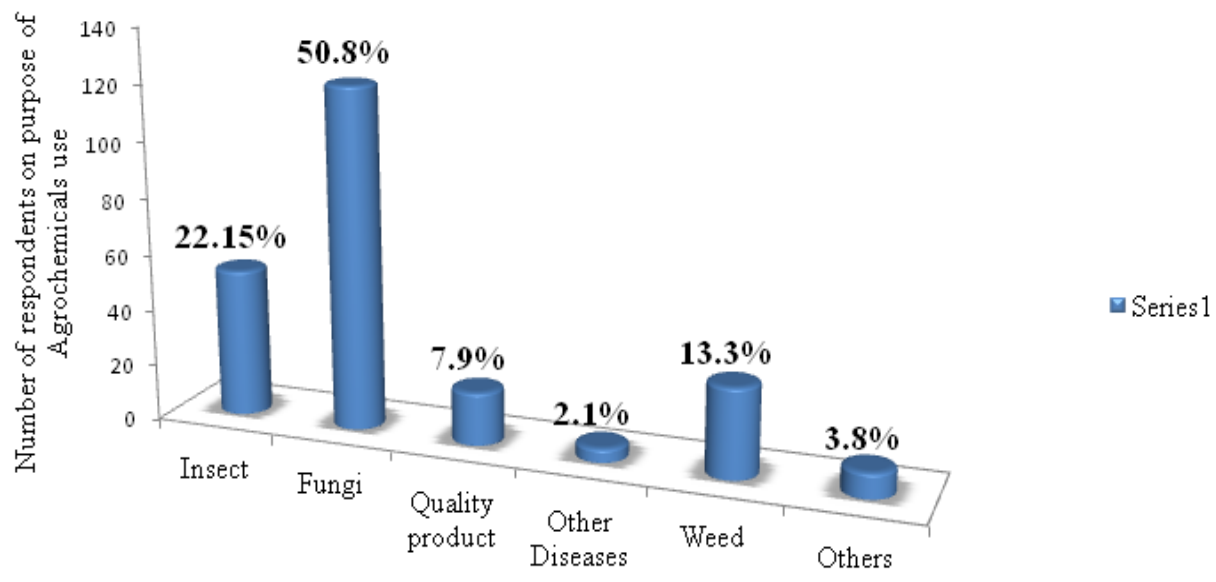

Figure2. Proportion of responses according to purpose of use of agrochemicals

It was explored that farmers practiced different methods of agrochemicals application at each sample districts (Table 6).In this manner,(78.3\%,75\%,100\% and 85\%), (15\%,18.35,0\% and 15\%) and 
$(6.7 \%, 6.7 \%, 0 \%$ and 0\%) in Dugda, Negele Arsi, Dodola and Lume districts in the form of spray, dust and fumigation respectively. Looking in the decreasing order of importance the respondents had used spray, dust and fumigation forms of agrochemicals application in all study districts.

The other factor described in this study was distribution of growth stage of the crop on which agrochemicals were applied at the study districts (table 6). Accordingly, $(35 \%, 30 \%, 53.3 \%$ and $43.3 \%),(55 \%, 51.7 \%, 35 \%$ and $51.7 \%),(0 \%, 6.7 \%, 0 \%$ and $0 \%)$ and $(6.7 \%, 28.3 \%, 11.7 \%$ and $5 \%)$ applied agrochemicals in Dugda, Negele Arsi, Dodola and Lume at 'vegetative', 'vegetative\& flowering', 'seed setting' and 'any stage' of growth of the cultivated crops respectively. However, as compared to others

Table6. Stage of crop and methods of agrochemicals application in the study districts

\begin{tabular}{|c|c|c|c|c|c|c|c|c|c|}
\hline \multirow{2}{*}{\multicolumn{2}{|c|}{$\begin{array}{l}\text { Agrochemicals utilization } \\
\text { practices }\end{array}$}} & \multicolumn{8}{|c|}{ Agrochemicals utilization practices in the study districts } \\
\hline & & \multicolumn{2}{|c|}{ Dugda } & \multicolumn{2}{|c|}{ Negele Arsi } & \multicolumn{2}{|c|}{ Dodola } & \multicolumn{2}{|c|}{ Lume } \\
\hline & & (n) & $(\%)$ & (n) & $(\%)$ & (n) & (\%) & (n) & $(\%)$ \\
\hline \multirow{3}{*}{$\begin{array}{l}\text { Method of } \\
\text { agrochemica } \\
\text { ls } \\
\text { application }\end{array}$} & Spraying & 47 & 78.30 & 45 & 75.00 & 60 & 100.00 & 51 & 85.00 \\
\hline & Fumigation & 9 & 15.00 & 11 & 18.30 & 0 & 0.00 & 9 & 15.00 \\
\hline & Dusting & 4 & 6.70 & 4 & 6.70 & 0 & 0.00 & 0 & 0.00 \\
\hline \multirow{4}{*}{$\begin{array}{c}\text { Stage of } \\
\text { crop at } \\
\text { agrochemica } \\
\text { ls } \\
\text { application }\end{array}$} & Vegetative & 21 & 35.00 & 18 & 30.00 & 32 & 53.30 & 26 & 43.30 \\
\hline & $\begin{array}{l}\text { Vegetative } \\
\text { and } \\
\text { flowering }\end{array}$ & 33 & 55.00 & 31 & 51.70 & 21 & 35.00 & 31 & 51.70 \\
\hline & Seed setting & 0 & 0.00 & 4 & 6.70 & 0 & 0.00 & 0 & 0.00 \\
\hline & Any stage & 4 & 6.70 & 17 & 28.30 & 7 & 11.70 & 3 & 5.00 \\
\hline
\end{tabular}

According to the result of this survey majority $(46.6 \%)$ of the respondents apply the chemicals during winter and about $20 \%$ of the respondents apply the chemicals during summer.13.8\% of the respondents apply agrochemicals both in winter and summer and $10 \%$ of the respondents apply during autumn. Not much but like $4.2 \%$ of the respondents apply during spring and the rest $7.9 \%$ apply at any season.

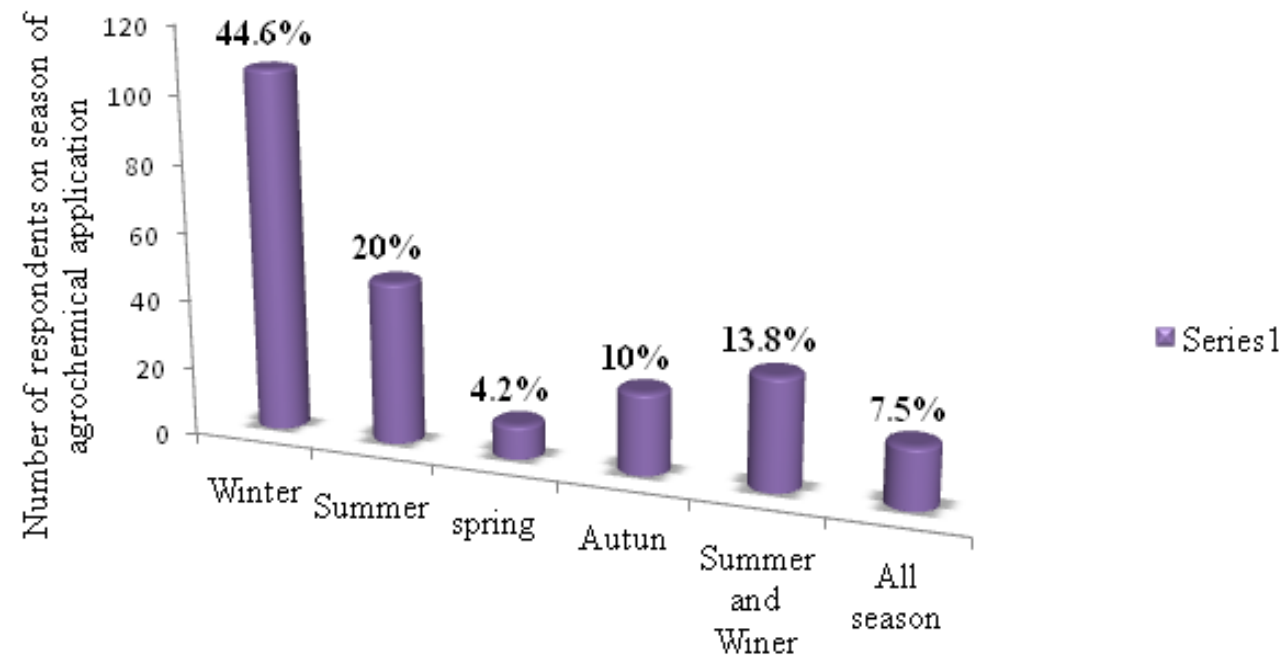

Figure3. Proportion of responses according to season of agrochemicals application

With regard to day time pattern of agrochemicals application (fig.4), the majority of respondents $(44.2 \%)$ stated that agrochemicals are applied in the morning time. Other significant number of respondents (35\%) cited 'afternoon' as preferable time for agrochemicals application. And like $15 \%$ of the respondents did apply agrochemicals in the evening while only $5.8 \%$ of them had applied at the midday. According to the results reported by Desalegn Begna (2015) though $64.4 \%$ of the userse at wesern Amhara prefer 6:00-9:00am as appropriate spray time, applications times are fixed by Knapsack renters and forced to spray at convenient time of knapsack renters. 


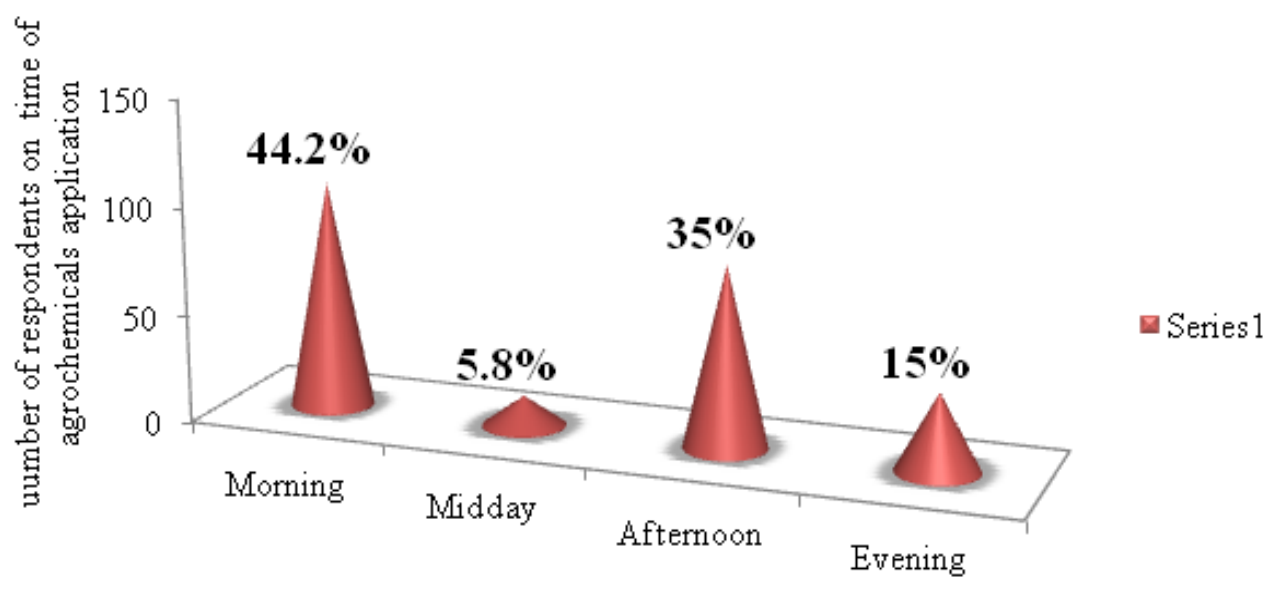

Figure4. Proportion of responses according to time of application of agrochemicals

As the pesticide knowledge was examined in this work (figure 5), 63.8\% of the respondents mentioned that they are able to read and understand information on labels of pesticide use instruction whereas $67.9 \%$ of the respondents indicated that they are able to understand information on pamphlets. But $70.9 \%$ of the respondents get help to read and understand information on pamphlets.

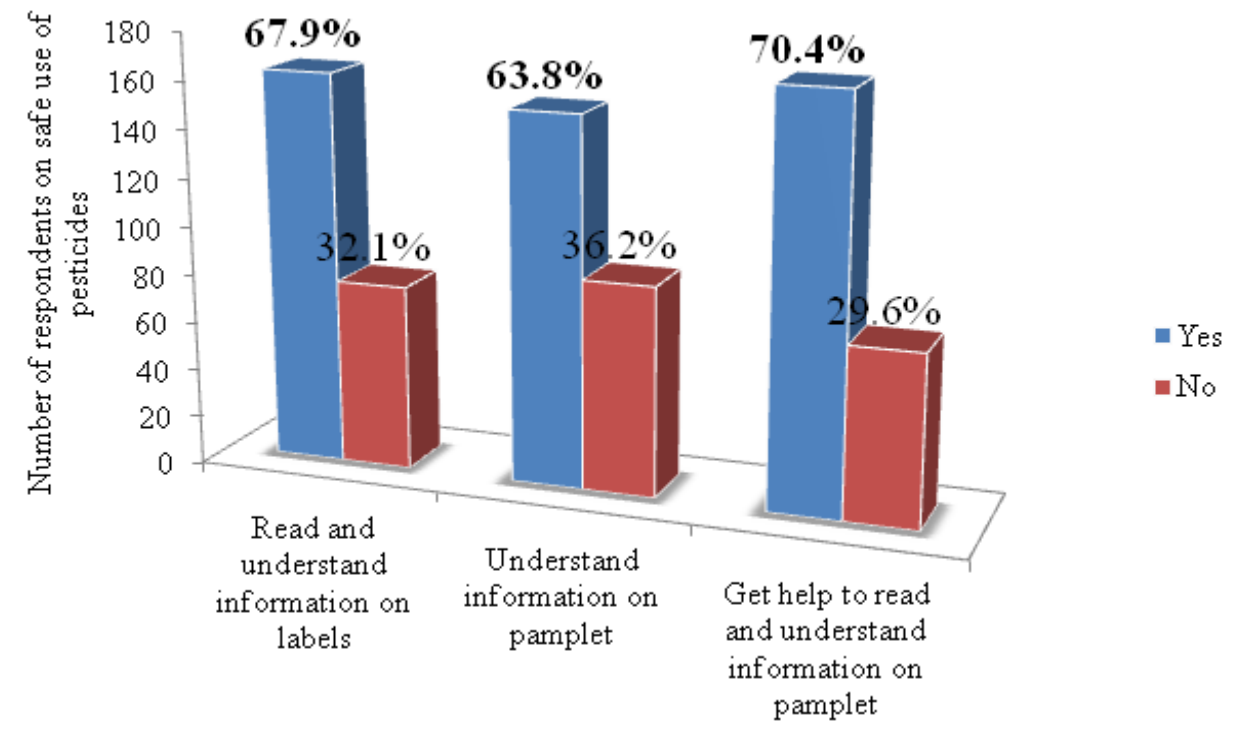

Figure5. Proportion of responses of respondents understanding on instruction of safe use of agrochemicals

\subsection{Perceived Effects of Agrochemicals on Beekeeping}

Like 58.8\% (Table 7) of the respondents responded that agrochemicals do harm honeybees. Furthermore, the respondents mentioned that agrochemicals affect honeybees and beekeeping in different ways. Accordingly, the respondents experienced/observed that agrochemicals: killed honeybees in sprayed fields $(58.8 \%)$, killed honeybees inside the hive $(50.3 \%)$, caused absconding of honeybees $(78.3 \%$ ), caused dwindling of honeybees (79.6\%) and caused low production of honey product $(84.6 \%)$ in the study area.

Dead bees around the farm after the application of agrochemicals. As it is indicated in the table 31 , with regard to awareness of the beekeepers on agrochemicals effect on honeybees, $86.9 \%$ of the respondents clarified that they had got this notion from extension agents $(63.5 \%)$, from their own 
experience or personal observation (20.8\%) and lessons from collogues (9.7\%). This result agree with Desalegn Begna, 2015 who reported that $69 \%$ of the beekeepers have got an extension services and are already aware of when and how to properly use pesticides without producing effects on the environment and honeybees. Marta Zelalem, 2013 also reported 85\% of the Awareness on the nature of pesticide and their effect by farmers is crucial to prevent risk associated to pesticide application. However do farmers have awareness about health effects of various pesticides being utilized? Accordingly the perception of $93.8 \%$ of the farmers was considering pesticides as useful. $0.4 \%$ of the farmers perceived pesticide as always harmful.

From this we can conclude that almost all of the farmers need further training and education on pesticide management, handling and associated adverse effects.

As the harmful effects of pesticides, $0.3 \%$ of farmers indicated that pesticides cause damage to all human, animal and wildlife health and water bodies and the remaining did not responds the angle of its effect. In line with the damages pesticides could cause, the farmers were asked if it would be possible to protect the damage and only $0.2 \%$ of them responded that it is possible.

Table7. Response frequency of knowledge of respondents on impact of agrochemicals on beekeeping

\begin{tabular}{|c|c|c|c|}
\hline Variables & Values & $(\mathrm{n})$ & $(\%)$ \\
\hline $\begin{array}{c}\text { Do you believe agrochemicals harm } \\
\text { honeybees }\end{array}$ & Yes & 141 & 58.75 \\
\hline & No & 99 & 37.97 \\
\hline Dead bees in the sprayed field & Yes & 71 & 29.58 \\
\hline Dead bees in the hives & No & 139 & 57.92 \\
\hline Absconding of bees & Yes & 122 & 50.83 \\
\hline & No & 118 & 49.20 \\
\hline Dwindling of honeybees & Yes & 188 & 78.30 \\
\hline & No & 52 & 21.70 \\
\hline Low production of honey & Yes & 191 & 79.58 \\
\hline & Yes & 49 & 20.42 \\
\hline
\end{tabular}

\subsection{Estimated Loss of Honeybee Colonies and Honey Product Due to Agrochemicals}

In the present study, $60.2 \%$ of the total respondent lost colonies due to the agrochemicals sprayed on different crops. This is slightly lower than the findings of Marta Zelalem (2013) who reported that $70.8 \%$ of the total respondent lost colonies due to the agrochemicals sprayed on different crops at Mecha district of western Amhara Region. The respondents were also pointed out the major signs observed on honeybees due to chemical poisoning like worker bee death at hive entrance $(72.8 \%)$, massive death (17.7\%), dead brood (5.8) and aggressiveness (3.7\%). According to the survey result, the mean number of colonies lost due to agrochemicals was $3.78 \pm 0.378,2.36 \pm 0.217$ and 1.43 for traditional, movable frame and intermediate hives respectively. The estimated amount of honey from lost colonies is shown in Table 33. As a result of this, from the interviewed beekeepers alone a total an estimated price of 834,910 ETB were being lost from unwise use of agrochemicals. Desalegn Begna (2015) reported financial loss incurred due to the dead, absconded and dwindled honeybee colonies in western Amhara was estimated to about 819291.4 USD. Therefore, this increased and substantial loss of local honeybees necessiates the importance of protecting bees from pesticides in the study area (Desalegn Begna, 2015).

Table32. Number of colonies lost and honey lost with an estimated price due to agrochemical applications

Table8. Mean estimated economic loss of beekeeping because of agrochemicals application

\begin{tabular}{|c|c|c|c|c|c|c|c|c|c|}
\hline Hive type & \multirow{2}{*}{$\mathrm{N}$} & \multicolumn{2}{|c|}{ No of colonies lost } & \multicolumn{3}{|c|}{ Honey lost in Kg } & \multicolumn{3}{c|}{ Estimated price } \\
\cline { 3 - 11 } & & mean & SE & Sum & Mean & SE & Sum & mean & SE \\
\hline Traditional & 152 & 0.6 & 0.3 & 707 & 30.0 & 3.5 & 5579 & 2941.8 & 349.0 \\
\hline Intermediate & 7 & 1.4 & & 10 & 15.9 & 4.3 & 127 & 780.0 & 196.0 \\
\hline Movable frame & 81 & 2.4 & 0.2 & 191 & 39.2 & 5.6 & 3277 & 3217.7 & 331.1 \\
\hline
\end{tabular}




\section{CONCLUSION AND RECOMMENDATION}

The increase in pesticide use has gave rise to concerns about potential adverse effects on environment and biodiversity, particularly in countries where regulations are not strictly implemented and farmers' knowledge of safe handling procedures is often inadequate. This paper assesses the potential risk of pesticide use health effects on honeybee colonies and beekeeping activities in East Shoa and West Arsi zones of Oromia, Ethiopia by examining pesticide usage and application practices by smallholder farmers in the zones.

In the areas, most of the farmers extensively apply different brands of agrochemicals. Agrochemicals use practice by the farmers in the study area was found to be reckless and can potentially affect honeybee population and beekeeping activities in general.

Even though it is with an inconsistent distribution, in the zones, agrochemicals are applied at all seasons of the year to control agricultural crop pests and diseases in the study area. As a result, agrochemicals are often supposed to have considerable effects in killing honeybees and affecting beekeeping activities in general. To this evident, on the average, 1736, 4036 and 1890 honeybee colonies are dying, absconding and dwindling every year from each district, respectively. Adhering to the effects on honeybees, the average economic loss incurred through their products is estimated to 273097 USD per year per district. For this reasons, beekeepers identified indiscriminate applications of pesticides are as major constraints of beekeeping developments in their areas.

In conclusion, the study availed evident and balanced information on the side effects of pesticides on honeybees and their products that is leading to developing strategies, policy and practices towards mitigating the risks.

\section{RECOMMENDATION}

Mitigating damage of pesticide use to honeybees is the responsibility of all parties involved and requires concerted effort to minimize the risk. Hence, based on this study the below are presented as possible recommendations, which are aimed at minimizing the ill effects of pesticides on honeybees and their products.

Manual should be developed and farmers must be educated on how to use label instructions and put into practice safety measures like not to spray on blooming crops, to keep bee colony away from the farm receiving pesticides, adjust the application time to late evening etc.

Regulatory body that oversees the total supply, transportation, storage, appropriateness etc of pesticides at all levels should be in place.

Crops weed management practices known by the community like hand weeding should be capitalized at least for two reasons: to protect bees and the environment; and to ensure the products are natural.

Initiating community based bylaws that give full right of supervise and corrective measures to the community.

The Amhara regional state should have its own context beekeeping development strategy and regional apiculture resources development and protection policy cascaded from the national one.

Comprehensive research into the effects of pesticides on honeybees and their products decline to which this study targeted to contribute is important. As it is clear that, proper application of pesticide can minimize, the environmental and public health impacts being caused by inappropriate utilization of pesticides. Additional education is needed on the use of protection equipment and follow-up of protection precaution in the study area. The result of these study highlight the need for further study and monitoring of the level of different pesticides in different food crops including cereals and other biological samples. Key to effecting change in response to pesticide contaminations is community based programs that replace toxic pesticides with alternative non-chemical practices and products. Communities should adopt no-pesticide policies and

\section{REFERENCES}

[1] Asogwa, E. a. (2009). Problems associated with pesticide usage and application in Nigerian cocoa production: A review. Afr. J. Agr. Res. , 675-683. 
[2] Bura, A. R. (2013). The Impact of Pesticides on Honey Bees and Hence on. Animal Science and Biotechnologies .

[3] Douglas, B. (2019). Pesticides and pollinators: A socioecological synthesis. Science of the Total Environment, 012-1027.

[4] Muhammad.A., S. A. (2017). A review: risk assessment of pesticides on honey bee and pollination of agriculture crops in Pakistan. Asian J Agri \& Biol. , 140-150.

[5] S.K. Biswas, S. R. (2014). A Review on Impact of Agrochemicals on Human Health and. Plant Environment Development , 31-35,.

[6] Sánchez-Bayo, F. (2011). Impacts of Agricultural Pesticides on Terrestrial Ecosystems. Ecological Impacts of Toxic Chemicals , 63-87.

Citation: Desta Abi, et.al, "Assessment of Pesticide use Practice Impact on Honeybee Colony in Selected Districts of East Shoa and West Arsi Zones of Oromia, Ethiopia" International Journal of Research Studies In Biosciences (Ijrsb), Vol. 7, no. 8, pp. 13-23, 2019. http://Dx.Doi.org/10.20431/2349-0365.0708004

Copyright: (C) 2019 Authors. This is an open-access article distributed under the terms of the Creative Commons Attribution License, which permits unrestricted use, distribution, and reproduction in any medium, provided the original author and source are credited. 